Short Communication

\title{
LONG Y-ASSOCIATED (GATA) ALLELES WERE OBSERVED IN A FEW ETHNIC GROUPS IN ASIA
}

\author{
Shio Jean LIN, ${ }^{1, *}$ Yen Hsiu Ko, ${ }^{1}$ Yutaka NAKAHORI, ${ }^{2}$ \\ and Yasuo NAKAGOME ${ }^{2}$ \\ ${ }^{1}$ Department of Pediatrics, Division of Genetics, National Cheng \\ Kung University Hospital, Tainan 704, Taiwan \\ ${ }^{2}$ Department of Human Genetics, School of International Health. The University of Tokyo, \\ 7-3-1 Hongo, Bunkyo-ku, Tokyo 113, Japan
}

Summary A Y-associated polymorphic locus, DYS19, was analyzed in a few ethnic groups in Asia and compared with that in Caucasians and Negroes. The locus contains 4-nucleotide repeats, $(\mathrm{GATA})_{\mathrm{n}}$, and the length of the repeated segments can be determined by the polymerase chain reaction (PCR). The predominant allele was $202 \mathrm{bp}$ followed by $198 \mathrm{bp}$ in all the 3 Asian populations examined. Long repeats that were rare in other populations were found more frequently in these Asian populations.

Key Words Y chromosome, tetranucleotide repeats, Chinese, Evenks, Japanese

\section{Introduction}

DNA polymorphisms of human $\mathrm{Y}$ chromosome have been proposed as useful tools for the study of gene flow through paternal lineage between different ethnic populations. Unfortunately, only a very limited number of $\mathrm{Y}$-specific restriction fragment length polymorphisms have been detected by conventional methods (Nakagome et al., 1992). The $\mathrm{Y}$ chromosome contains tandem repetitive sequences. A polymorphism of a (GATA) $)_{n}$ tetranucleotide-repeat type has been identified (Arnemann et al., 1986) and this polymorphism can be examined by polymerase chain reaction (PCR) (Roewer et al., 1992). The allele distributions of this locus have been reported in various populations (Santos et al., 1993; Gomolka et al., 1994). In this report, we studied the polymorphism of this locus in five ethnic groups and compared to previous reports.

Received December 13, 1995; Revised version accepted March 12, 1996.

* To whom correspondence should be addressed. 


\section{Materials and Methods}

Blood samples of unrelated males were examined of five populations, 46 Chinese (Fo-Lo, Taiwan), 30 Japanese, 21 Evenks, 16 Caucasians and 14 Negroes. They were included in our previous study on the $47 \mathrm{z}$ locus (Lin et al., 1994). The set of oligonucleotide primers used were those designed by Roewer et al. (1992). They amplified clustered (gata) repeats in the DYS19 locus on Yp. The PCR reactions were carried out according to conditions at the following temperatures: denaturation at $94^{\circ} \mathrm{C}$ for $30 \mathrm{sec}$, annealing at $51^{\circ} \mathrm{C}$ for $30 \mathrm{sec}$, and extension at $72^{\circ} \mathrm{C}$ for $90 \mathrm{sec}$. Thirty cycles were carried out in a reaction volume of $25 \mu 1$ with $2 \mathrm{mM}$ $\mathrm{Mg}^{++}$. The PCR products were resolved in $20 \times 35 \mathrm{~cm}, 6 \%$ polyacrylamide gels (acrylamide : bisacrylamide $=30: 1$ ) in TBE buffer for $8 \mathrm{hr}$ at $150 \mathrm{~V}$. Following electrophoresis, the fragments are visualized and photographed under a UV light. For final analysis and documentation, the fragments were developed using silver staining with commercial kits (E Merck Co., Darmstadt, Germany).

\section{Results and Discussion}

The distribution of alleles were summarized in Table 1 . The predominant allele was different among populations studied: Taiwanese and Evenks had both $202 \mathrm{bp}$ and $198 \mathrm{bp}$ alleles, Japanese mostly $202 \mathrm{bp}$, and both Caucasians and Negroes in the USA had 194 bp. The longest 206 bp allele was observed only in Asian populations. The numbers of Caucasians and Negroes examined in the present study was very small. In Caucasians, there was also difference in frequencies of the alleles between studies by us and Roewer et al. (1992). The difference was considered as bias caused by our small sampling size. Rather, they were included in the present study to make lane to lane comparison between individuals who belong to different ethnic groups (Fig. 1).

The DYS19 locus has been examined in various populations. Among Caucasians in both Germany and Brazil (Gomolka et al., 1994; Santos et al., 1993), $190 \mathrm{bp}$ allele was most frequently observed. While in Middle East and South Asia, the predominant alleles were $194 \mathrm{bp}$ in Pakistani, Hindu, Thais and 198 bp in Kampuchea (Gomolka et al., 1994). In another survey of alleles at the

Table 1. Allele distributions of DYS19 (GATA) $n$ microsatellites.

\begin{tabular}{cccccll}
\hline Alleles & Chinese & Evenks & $\begin{array}{c}\text { Japanese } \\
\text { No. (\%) }\end{array}$ & Caucasians & Africans & Caucasians* \\
\hline & & \multicolumn{1}{c}{${ }^{*}$} & $\mathrm{n}=30$ & $\mathrm{n}=16$ & $\mathrm{n}=14$ & $\mathrm{n}=30$ \\
$186 \mathrm{bp}$ & 0 & 0 & 0 & 0 & 0 & $(13)$ \\
$190 \mathrm{bp}$ & 0 & 0 & 0 & $1(6)$ & 0 & $(47)$ \\
$194 \mathrm{bp}$ & 0 & $1(5)$ & $1(3)$ & $9(56)$ & $6(43)$ & $(23)$ \\
$198 \mathrm{bp}$ & $22(48)$ & $9(43)$ & $9(33)$ & $5(31)$ & $5(36)$ & $(17)$ \\
$202 \mathrm{bp}$ & $23(50)$ & $10(47)$ & $16(53)$ & $1(6)$ & $3(21)$ & 0 \\
$206 \mathrm{bp}$ & $1(2)$ & $2(5)$ & $4(13)$ & 0 & 0 & 0 \\
\hline
\end{tabular}

* Roewer et al., 1992. 

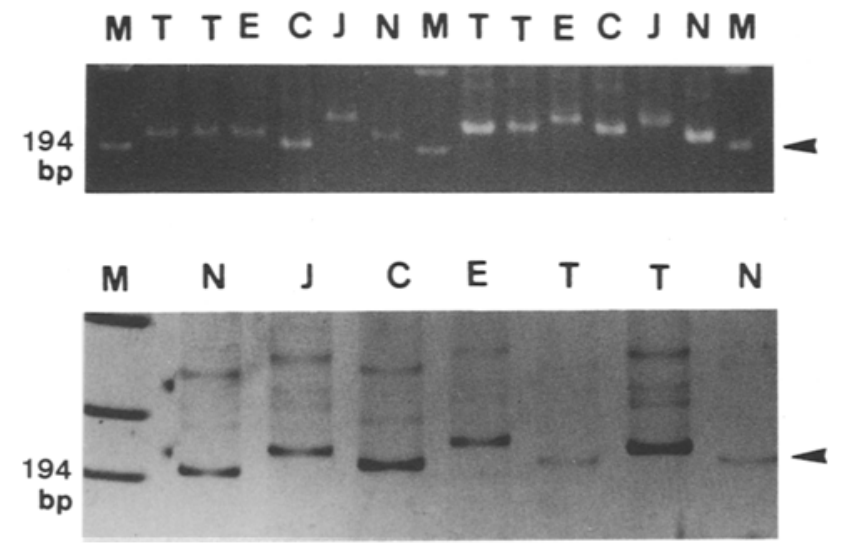

Fig. 1. Polyacrylamide gel electrophoresis of (GATA) repeats at DYS19 locus (indicated by arrow heads). The gel shown in the upper lane was stained with ethidium bromide after electrophoresis and gel in the lower lane was silver stained. HaeIII fragment of $\phi \mathrm{X} 174$ with sizes $310,281,271$ and $194 \mathrm{bp}$ were used as markers (M). T, Taiwanese; E, Evenks; C, Caucasians; J, Japanese; N, Negroes. The additional bands with higher molecular weights were possibly derived from non-specific amplification during PCR.

DYS19 locus, higher frequency of longer alleles was found in Japanese populations as compared to that of Western European populations (Hammer and Horai, 1995). The similar observation from our study and others suggest that Asians on average have longer alleles than Caucasians. This observation might provide some basic information on understanding of the evolution of these kinds of DNA repeats in the history of human migration.

Acknowledgments Evenks DNA were kindly supplied by Dr. M.H. Crawford, Kansas University. Supported in part by Grant-in-Aid for Creative Basic Research from the Ministry of Education, Science and Culture of Japan and National Science Council in Taiwan.

\section{REFERENCES}

Arnemann J, Jakubiczka S, Schmidtke J, Schafer R, Epplen JT (1986): Clustered GATA repeats (Bkm sequences) on the human Y chromosome. Hum Genet 73: 301-303

Gomolka M, Hundrieser J, Nurnberg P, Roewer L, Epplen JT, Epplen C (1994): Selected di- and tetranucleotide microsatellites from chromosomes 7, 12, 14 and $\mathrm{Y}$ in various Eurasian populations. Hum Genet 93: 592-596

Hammer MF, Horai S (1995): Y chromosomal DNA variation and the peopling of Japan. Am J Hum Genet 56: 951-956

Lin SJ, Tanaka K, Leonard W, Gerelsaikhan T, Dashnyam B, Nyamkhishig S, Hida A, Nakahori Y, Omoto K, Crawford MH, Nakagome Y (1994): A Y-associated allele is shared among a few ethnic groups of Asia. Jpn J Human Genet 39: 299-304

Nakagome Y, Young SR, Akane A, Numabe H, Jin DK, Yamori Y, Seki S, Tamura T, Nagafuchi S, Shiono H, Nakahori Y (1992): A Y-associated allele may be characteristic of certain ethnic groups in Asia. Ann Hum Genet 56: 311-314 
Roewer L, Arnemann J, Spurr NK, Grzeschik K-H, Epplen JT (1992): Simple repeat sequences on the human $\mathrm{Y}$ chromosome are equally polymorphic as their autosomal counterparts. Hum Genet 89: 389-394

Santos FR, Pena SDJ, Epplen JT (1993): Genetic and population study of a Y-linked tetranucleotide repeat DNA polymorphism with a simple non-isotopic technique. Hum Genet 90: $655-656$ 